\title{
Determination of Iron (Fe), Zinc (Zn) Levels and Organoleptic Tests in Coconut Pulp Flour
}

Muh. F. Khaykal \& *Sri H. V. Pulukadang

Program Studi Pendidikan Kimia/FKIP - Universitas Tadulako, Palu - Indonesia 94119

Received 29 September 2021, Revised 18 October 2021, Accepted 19 November 2021

doi: 10.22487/j24775185.2021.v10.i4.pp269-276

\begin{abstract}
Coconut pulp is a by-product of coconut milk which contains high protein and good nutrition. This study aimed to determine the iron $(\mathrm{Fe})$ and zinc $(\mathrm{Zn})$ levels in coconut pulp flour using atomic absorption spectrophotometry and determine the characteristics of coconut pulp flour using organoleptic tests. The results showed that iron (Fe) level was $44.075 \mathrm{mg} / \mathrm{Kg}$ and zinc $(\mathrm{Zn})$ was $24.2 \mathrm{mg} / \mathrm{kg}$. The organoleptic characteristics of the pulp were white and brownish for the dry powder, coconut-scented, a powder-shaped texture, and normal taste. The highest percentage level of hedonic scale for each criterion was $64 \%$ preferred for color, $52 \%$ preferred for aroma, $48 \%$ preferred for texture, and $52 \%$ preferred for taste. Based on these results, coconut pulp can be an alternative local food to meet iron and zinc needs for humans. The processing of coconut pulp as food can be used as a substitute flour in making bread, cakes, cookies, and other food preparations.
\end{abstract}

Keywords: Coconut pulp, flour, atomic absorption spectrophotometry (AAS), iron, zinc, organoleptic test

\section{Introduction}

Coconut (Cocos nucifera L) is a commodity plant that grows and develops well in Indonesia. In particular, this plant grows along sandy beaches and can grow in highland areas. This plant is a multifunctional plant because almost all plant parts can be used properly to meet the community's food needs. Some processed products produced from coconut plants are coconut milk, sugar, and coconut water (Saepulah et al., 2017).

Coconut plants have many uses due to the presence of nutrients such as sugar, protein, vitamins, and phytochemical compounds and organic compounds in them (Ouma et al., 2019). Coconut plants with various uses have many processed products for food needs, especially the part of the coconut flesh, the most widely used. Coconut flesh has several nutritional contents such as water, protein, fat, carbohydrates, fiber, sugar, iron, magnesium, phosphorus, potassium, sodium, zinc, copper, etc. Coconut flesh as a food product is mainly used for coconut milk. Coconut milk is a natural oil-water emulsion that is sweet and milky in color. Coconut milk is traditionally processed in Southeast Asia, including Indonesia (Victor \& Elijah, 2016). Processing of coconut flesh into coconut milk has a by-product or waste that is rarely used, namely coconut pulp. The coconut dregs produced from processing coconut milk are thrown away. Even though coconut pulp is a by-product, it still has a relatively high protein content (Silvia $\&$ Widodo, 2018).

Coconut dregs, a by-product of the processing coconut fruit, still have advantages as a supporter of sustainable food security; this is supported by high production potential. The process and equipment used in its production are inexpensive and straightforward. They can be processed into higher quality products and added to bakery products, food recipes, and other food products. (Angelia, 2016).

The by-product or waste from coconut fruit processing currently has not been used optimally by the community and is only considered as waste even though the diversification results of coconut fruit waste processing have economic added value and have a high selling value. (Lestari et al., 2019).

Several studies have been conducted to reduce coconut pulp waste. One of the results of food products intended to develop processed coconut waste products is to become coconut pulp flour (Silvia \& Widodo, 2018). However, coconut pulp flour as a local food ingredient is still not widely used by the community. In some processed food products, flour is still dominated by wheat flour (Hasan, 2018).

Flour consumed as a food ingredient has been regulated by the National Standardization Agency (BSN), wheat flour. The flour must meet the test of appropriateness standards intended to protect

*Correspondence:

Sri H. V. Pulukadang

e-mail: srihastutibulo@yahoo.com

(c) 2021 the Author(s) retain the copyright of this article. This article is published under the terms of the Creative Commons Attribution-NonCommercial-ShareAlike 4.0 International, which permits unrestricted non-commercial use, distribution, and reproduction in any medium, provided the original work is properly cited. 
consumers' health. In general, the flour used as food ingredients has been regulated by BSN, which includes the physical properties of flour such as color, texture, aroma, and taste. Likewise, some are iron $(\mathrm{Fe})$ and zinc (Zinc) with metal ions in flour. The quality requirements for iron ion $(\mathrm{Fe})$ content are a minimum of $50 \mathrm{mg} / \mathrm{kg}$ and a minimum of 30 $\mathrm{mg} / \mathrm{kg}$ for zinc $(\mathrm{Zn})$.

Iron and zinc are essential metals needed by humans in small amounts $<100 \mathrm{mg} / \mathrm{day}$ (Mulyaningsih, 2013). As important metals required by the body, these two substances have several functions. One of them, iron, functions as a red blood cell-forming agent and an activator of several enzymes and antibody-forming enzymes (Hamzah \& Yusuf, 2019). Just as iron has an essential function for the body, zinc also functions for cell regeneration, helps prevent cell oxidation, and helps children's growth and development process. (Riskiyah, 2017).

Coconut dregs flour, which is diversified as a local food ingredient, requires a preliminary test using several panelists to test the organoleptic properties of flour. In the future, it is hoped that it can be used as a food product with high acceptability and can be one of the food choices in its development (Putri et al., 2018).

This study aims to utilize coconut dregs processed into coconut dregs flour based on the description above. As flour is used as a food ingredient, further knowledge is needed about the mineral content of coconut dregs flour, especially iron and zinc minerals, and additional knowledge about the organoleptic properties of coconut dregs flour. Therefore, this study was conducted to determine the levels of iron $(\mathrm{Fe})$, zinc $(\mathrm{Zn})$, and organoleptic tests on coconut pulp flour. It is hoped that this research will be an effort to reduce environmental pollution from coconut dregs. The results of processing coconut dregs, namely coconut dregs flour, can be utilized optimally.

\section{Methods}

This research is experimental research conducted in the laboratory Chemistry Education Tadulako University and the Health laboratory of Palu City, Central Sulawesi Province.

\section{Tools and materials}

The tools used are a baking sheet, blender, oven, 70 mesh sieve, dropper, $100 \mathrm{~mL}$ volumetric flask, $50 \mathrm{~mL}$ beaker, stir bar, electric bath, digital balance, funnel, spatula, SSA tools, watch glass, and spatula. The materials used were coconut pulp, aquades, nitric acid $\left(\mathrm{HNO}_{3}\right)$ 65\%, standard solution of iron $(\mathrm{Fe})$, and zinc $(\mathrm{Zn})$.

\section{Making coconut dregs flour}

The coconut pulp sampling process was carried out at the Inpres market in Palu City. Then the coconut pulp is put into a container and washed to separate the coconut pulp from the husk. The cleaned coconut dregs were then dried using an oven at $70^{\circ} \mathrm{C}$ for 6 hours. After drying, the coconut pulp is mashed using a blender. Blended coconut dregs, then sieved using a 70 mesh sieve.

\section{Preparation of sample}

Two grams of coconut pulp flour are put into a $50 \mathrm{~mL}$ beaker, dissolved with $10 \mathrm{~mL}$ of concentrated $\mathrm{HNO}_{3}$ then added with $20 \mathrm{~mL}$ of distilled water. After that, it is heated using an electric bath and stirred using a stirring rod until all the samples in the beaker are completely dissolved and not again visible yellowish gas vapor. After all the samples were completely dissolved, the sample solution was filtered using filter paper into a $100 \mathrm{~mL}$ volumetric flask until the filtrate and residue separated. The filtered filtrate obtained was diluted using distilled water gradually as much as $10 \mathrm{~mL}$ for each addition; the addition of $10 \mathrm{~mL}$ of distilled water was repeated until the $100 \mathrm{~mL}$ volumetric flask was marked.

Preparation of standard solutions of Fe and $Z n 100$ ppm

Standard solutions of $100 \mathrm{ppm} \mathrm{Fe}$ and $\mathrm{Zn}$ were obtained from 1000 ppm mother liquor; each 10 $\mathrm{mL}$ of the mother liquor was pipetted into different $100 \mathrm{~mL}$ volumetric flasks. Then diluted using distilled water whose volume is set to the limit mark.

\section{Calibration curve creation}

From a standard solution of $100 \mathrm{ppm} \mathrm{Fe,} \mathrm{a}$ standard series was made as follows; $0.05 \mathrm{ppm} ; 0.1$ ppm; $0.5 \mathrm{ppm} ; 1.0 \mathrm{ppm}$; and $1.5 \mathrm{ppm}$. Likewise, with the standard solution of $100 \mathrm{ppm}$ Fe. Then, the absorbance was measured using AAS in the standard series of the two solutions. The absorption data of the two solutions, a calibration curve were made using Microsoft excel.

\section{Content of iron ( $\mathrm{Fe})$ and zinc $(\mathrm{Zn})$}

$\mathrm{Fe}$ and $\mathrm{Zn}$ levels were determined by measuring the absorption using an AAS device at a wavelength of $248.30 \mathrm{~nm}$ for $\mathrm{Fe}$ and $\mathrm{Zn}$, and the absorption was measured at a wavelength of 213.90 $\mathrm{nm}$. Measurement of sample uptake was repeated twice.

The data obtained from the absorption of the sample solution were then analyzed to obtain the concentrations of $\mathrm{Fe}$ and $\mathrm{Zn}$ in the sample using the standard solution calibration curve regression equation (Alizah et al., 2019):

$$
\mathrm{Y}=\mathrm{a}+\mathrm{b} \cdot \mathrm{X}
$$

where $\mathrm{Y}$ is the value of Absorbance (A); $\mathrm{a}$ is a constant (a constant); $\mathrm{b}$ is the slope of the line, and $\mathrm{X}$ is the sample concentration $(\mathrm{mg} / \mathrm{L})$. Determination of the levels of $\mathrm{Fe}$ and $\mathrm{Zn}$ in the sample used the following equation:

$$
Y=\frac{\mathrm{q} \cdot \mathrm{N}}{\mathrm{p}}
$$

where $\mathrm{M}$ is the content of $\mathrm{Fe}$ and $\mathrm{Zn}(\mathrm{mg} / \mathrm{kg})$; $\mathrm{q}$ is the sample determination volume $(\mathrm{L}) ; \mathrm{N}$ is the 
concentration of the sample solution $(\mathrm{mg} / \mathrm{L})$, and $\mathrm{P}$ is the dry weight of the sample.

\section{Organoleptic test}

Organoleptic tests were carried out by taking into account the characteristics of the test samples, which included indicators of color, aroma, texture, and taste. Then a hedonic test was carried out to assess the level of preference of the authors for coconut dregs flour. There were 25 researchers in this test, and the test was carried out by presenting coconut dregs flour using a watch glass to each panelist. Then the panelists were given a questionnaire to fill in according to their respective opinions regarding their level of preference.

The hedonic test data obtained from the researchers were collected and processed manually and then analyzed using descriptive percentage analysis. The score to get the percentage of the panelist's preference level is formulated as follows:

$$
\text { Percentage }(\%)=\frac{n}{N} \times 100
$$

where $\%$ is the percentage score; $\mathrm{n}$ is the number of scores obtained; $\mathrm{N}$ is the ideal score (highest score $\mathrm{x}$ number of panelists). The score obtained can be known by the preference level based on the percentage interval and the test preference criteria. Existing criteria are very like, like, somewhat like, dislike and dislike very much. The percentage interval and preference criteria can be seen in Table 1.
Table 1. Percentage interval and preference criteria

\begin{tabular}{cc}
\hline $\begin{array}{c}\text { Percentage } \\
(\%)\end{array}$ & Favorite criteria \\
\hline $84-100$ & Really like \\
$68-83.99$ & Likes \\
$52-67.99$ & Somewhat like \\
$36-51.99$ & Dislikes \\
$20-35.99$ & Dislike very much \\
\hline
\end{tabular}

\section{Results and Discussion}

The results of the research regarding the determination of the levels of iron $(\mathrm{Fe})$, zinc $(\mathrm{Zn})$, and organoleptic tests on coconut pulp flour obtained data regarding the concentrations of $\mathrm{Fe}$ and $\mathrm{Zn}$ in the sample solution of coconut pulp flour $(\mathrm{mg} / \mathrm{L})$ and the levels of Fe and $\mathrm{Zn}$ in the sample flour $(\mathrm{mg} / \mathrm{kg})$ and flour organoleptic test results coconut pulp.

Determination of the concentration of $\mathrm{Fe}$ and $\mathrm{Zn}$ was carried out using the results of the absorption of standard solutions of $\mathrm{Fe}$ and $\mathrm{Zn}$. The results of the absorption, obtained $\mathrm{Fe}$ and $\mathrm{Zn}$ calibration curves which can be seen in Figures 1 and 2.

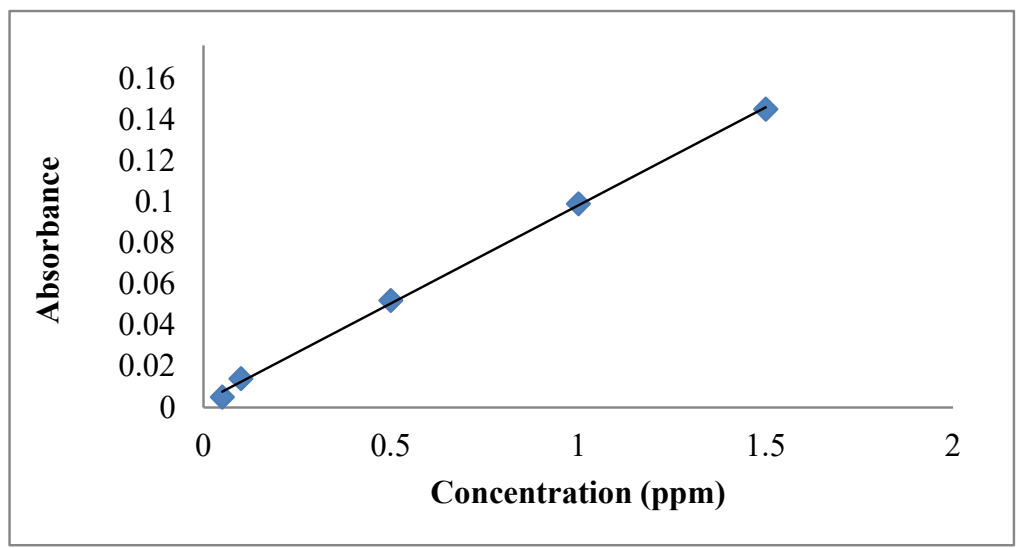

Figure 1. Solution calibration curve Fe standard 


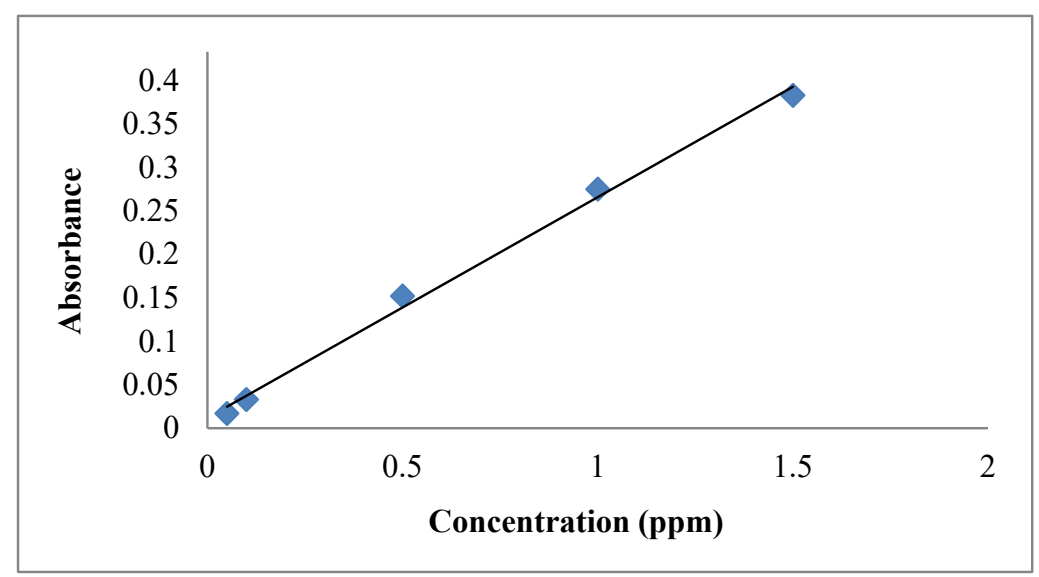

Figure 2. Solution calibration curve $\mathrm{Zn}$ standard

Based on the calibration curve data obtained, the regression equation line for $\mathrm{Fe}$ is $\mathrm{y}=0.0954 \mathrm{x}+$ 0.0029 and $0.2538 x+0.383$ for $\mathrm{Zn}$. The regression equation line is used to analyze the concentration of $\mathrm{Fe}$ and $\mathrm{Zn}$ in the sample solution. Then the results of the concentration analysis in the sample solution were used to calculate the levels of $\mathrm{Fe}$ and $\mathrm{Zn}$ in coconut pulp flour using the equation.

$$
Y=\frac{\mathrm{q} \cdot \mathrm{N}}{\mathrm{p}}
$$

Based on the calculation results, data on Fe and $\mathrm{Zn}$ levels in coconut dregs flour can be seen in Tables 2 and 3.

Table 2. Concentration of iron $(\mathrm{Fe})$ content in coconut dregs flour

\begin{tabular}{ccccc}
\hline No & Repetition & Absorbance & $\begin{array}{c}\text { Concentration } \\
(\mathrm{mg} / \mathrm{L}\end{array}$ & $\begin{array}{c}\text { Level } \\
((\mathrm{mg} / \mathrm{Kg})\end{array}$ \\
\hline 1 & 1 & 0.086 & 0.871 & 43.55 \\
2 & 2 & 0.088 & 0.892 & 44.60 \\
& Avarage & 0.087 & 0.881 & 44.075 \\
\hline
\end{tabular}

Table 3. Concentration of zinc ( $\mathrm{Zn})$ levels

\begin{tabular}{ccccr}
\multicolumn{5}{c}{ in coconut dregs flour } \\
\hline \multirow{2}{*}{ No } & Repetition & Absorbance & $\begin{array}{c}\text { Concentration } \\
(\mathrm{mg} / \mathrm{L}\end{array}$ & $\begin{array}{c}\text { Level } \\
((\mathrm{mg} / \mathrm{Kg})\end{array}$ \\
\hline 1 & 1 & 0.135 & 0.484 & 24.2 \\
2 & 2 & 0.135 & 0.484 & 24.2 \\
& Avarage & 0.135 & 0.484 & 24.2 \\
\hline
\end{tabular}

The characteristics of the coconut dregs flour produced are white, brown pollen, a characteristic coconut aroma, the texture of the powder is ordinary. Coconut dregs flour can be seen in Figure 3. 


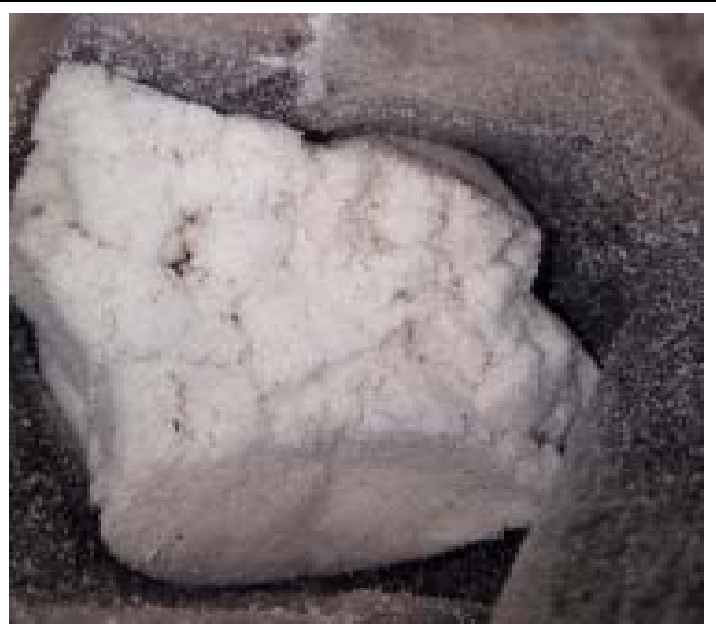

Figure 3. Coconut dregs flour

The percentage level of an enormous hedonic scale of coconut pulp flour for each criterion can be seen in Table 4.

Table 4. The percentage level of the most significant hedonic scale of coconut dregs flour

\begin{tabular}{ccc}
\hline $\begin{array}{c}\text { Indicat } \\
\text { or }\end{array}$ & $\begin{array}{c}\text { Percentage } \\
(\%)\end{array}$ & $\begin{array}{c}\text { Favorite } \\
\text { criteria }\end{array}$ \\
\hline Color & 64 & Likes \\
Aroma & 52 & Likes \\
Texture & 48 & Kinde like \\
Flavor & 52 & Kinde like \\
\hline
\end{tabular}

\section{Content of iron ( $\mathrm{Fe})$ and zinc $(\mathrm{Zn})$}

After being analyzed and calculated, the average levels of $\mathrm{Fe}$ and $\mathrm{Zn}$ in coconut dregs flour were $44.075 \mathrm{mg} / \mathrm{kg}$ for $\mathrm{Fe}$ and $\mathrm{Zn}$, namely 24.2 $\mathrm{mg} / \mathrm{kg}$. The results obtained can be seen in Figure 3.

Iron and zinc are minerals contained in the flesh of coconut (Coconut Nucifera L). Iron is an essential mineral because the body needs it to form blood. Also, iron has a vital role in distributing oxygen in human blood, which maintains immunity. One of the effects of a lack of iron intake can cause anemia and lower immunity (Kurniawati \& Sugiarso, 2016).

Zinc $(\mathrm{Zn})$ is a macromineral found in all body cells of living things, including humans. As a mineral needed by the body, it is necessary to pay attention to the nutritional intake of zinc minerals because a lack of zinc intake can cause disturbances in the digestive system (Handayani et al., 2016).

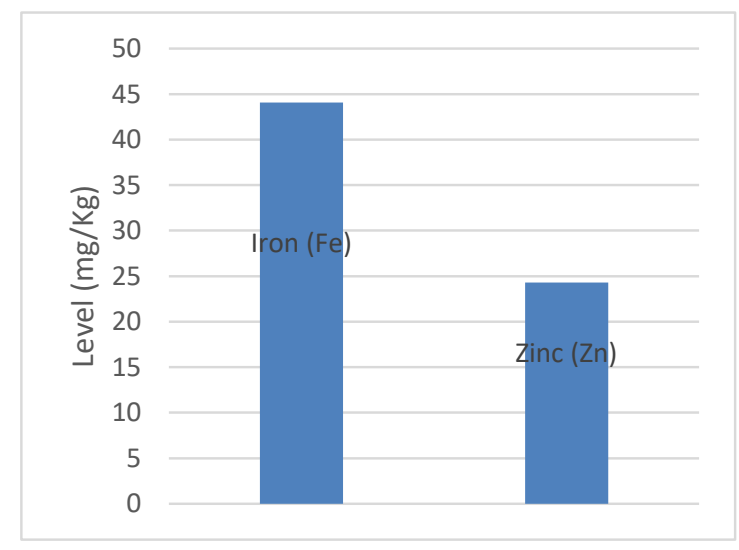

Figure 4. The average levels of $\mathrm{Fe}$ and $\mathrm{Zn}$ in coconut dregs flour.

The mineral content of wheat flour, which is used as a food ingredient, has been regulated according to the quality requirements of the national standardization body, which was made to protect consumers' health. For quality requirements, the iron content in wheat flour is at least $50 \mathrm{mg} / \mathrm{kg}$ and zinc at least $30 \mathrm{mg} / \mathrm{kg}$.

This research was conducted to determine the levels of iron and zinc in dregs flour. Then the results obtained were compared to the data with iron and zinc levels in wheat flour because we 
wanted to see how the mineral content of the two differs and the potential for developing coconut dregs flour.

Compared with the research results conducted by Rahmawati et al. (2015), which used white sweet potato flour and purple sweet potato flour as ingredients for making bread. The iron content of coconut pulp flour $(44.075 \mathrm{mg} / \mathrm{kg})$ was higher than the iron content of white sweet potato flour (42.679 $\mathrm{mg} / \mathrm{kg}$ ), and the zinc content of coconut pulp flour was also higher $(24.2 \mathrm{mg} / \mathrm{kg})$ than the zinc content of sweet potato flour white sweet potato (2.7017 $\mathrm{mg} / \mathrm{kg}$ ). Compared with the results studied, the iron content of purple sweet potato flour was higher $(51.531 \mathrm{mg} / \mathrm{kg})$. And then, the zinc content of purple sweet potato flour $(7.846 \mathrm{mg} / \mathrm{kg})$ was lower than coconut pulp flour.

The mineral content in coconut dregs flour shows that coconut dregs flour is a source of food containing iron and zinc minerals. The results of this study are in line with the results of research conducted by Widiastuti et al. (2015). This study found that market coconut pulp flour has an iron mineral content of $31.97 \mathrm{mg} / \mathrm{L}$ and coconut pulp flour virgin coconut oil (VCO). has an iron mineral content of $75.1 \mathrm{mg} / \mathrm{L}$. Based on the description of the research results obtained above, these results indicate that coconut pulp flour can be a source of food ingredients that can meet the body's nutritional needs, especially the intake of iron and zinc minerals. The body requires iron and zinc intake in <100 mg/day (Mulyaningsih, 2013). Therefore, flour from coconut pulp can be used as an alternative to local food ingredients to meet iron and zinc needs in the body.

\section{Organoleptic test}

There were 25 authors in this study. The panelists conducted an organoleptic test or hedonic test to give their opinion about their level of preference for coconut dregs flour. Test the level of preference using six scales consisting of; like very much (5), like (4), like somewhat (3), dislike (2), and strongly dislike (1). The results of the hedonic test are described as follows:

\section{Color criteria}

Color is an essential component for the acceptance criteria of a food ingredient. A food ingredient with an unattractive color or a color that deviates from that which should not be consumed. So that the acceptance of the quality of food generally depends on the color that is seen first (Herlambang et al., 2019).

In the resulting coconut pulp flour, the flour is white. Based on the percentage of the level of preference testing, the highest level of preference was obtained, namely $64 \%$ or the like category. Then $28 \%$ of the panelists chose the type rather like it; this was because there was still a brownish color of the powder in the flour caused by grating the coconut pulp, the epidermis of the coconut meat was carried away. The level of preference for coconut dregs flour, which reached $64 \%$ in the liking category, was influenced by the temperature and duration of the heating process. Drying for 6 hours at $70{ }^{\circ} \mathrm{C}$ is the best heating process to get coconut pulp flour with the highest degree of whiteness (Azis \& Akolo, 2018).

\section{Aroma criteria}

Aroma is a criterion for organoleptic testing using the sense of smell. Based on the percentage of testing the level of liking for the aroma category, the highest level of preference was found, namely $52 \%$ or the like type. Then $28 \%$ love the fragrance of coconut dregs flour.

The coconut dregs flour produced has a distinctive aroma, namely the aroma of coconut. The process of making coconut dregs flour affects the smell produced. Coconut dregs flour has a reasonably distinctive aroma, namely the distinctive aroma of coconut (Putri, 2014).

\section{Texture criteria}

The texture or shape of flour is one of the criteria for testing, which is done by touching the test sample. Based on the percentage level of preference for the texture of coconut pulp, the highest level of preference was found, namely $48 \%$ who stated that they liked it somewhat and $44 \%$ said they wanted it.

The texture of a food ingredient such as flour is influenced by several factors: water content. High water activity in the material will affect the acceptance of the texture of a product (Aminah et al., 2018). Coconut dregs flour produced by its fineness level is still below that of wheat flour; this is because wheat flour in the manufacturing process uses a 100 mesh sieve to make the resulting texture smoother (Putri, 2014).

\section{Taste criteria}

Taste is an evaluation criterion that uses the sense of the tongue. Based on the percentage level of preference results, the taste of coconut dregs flour was found to be $52 \%$, stating that they liked it somewhat and 32\% said they didn't like it.

Taste is an essential parameter to determine the acceptance of a food ingredient. Each flour has a distinctive and different taste; the taste is judged based on a person's response after receiving a stimulus on the tongue. When tested to panelists for coconut dregs flour, the existing panelists are unfamiliar with the resulting taste and will judge it as normal. Therefore, to receive better taste parameters from coconut pulp flour, further treatment is needed to be tested in making brownies. Making brownies mixed with coconut dregs flour will give a distinctive and more dominant coconut taste so that the level of taste acceptance in coconut dregs flour will be better (Hasan, 2018). Coconut dregs flour can be used as a food ingredient by paying attention to processed.

Processing coconut dregs flour as an ingredient for the manufacture of several processed foods can 
be used as the main ingredient or as a substitute for several types of flour. Research conducted by (Herni et al., 2018) utilizes coconut pulp flour in the manufacture of high-fiber biscuits. Likewise, with research conducted by (Mulyati et al., 2019), coconut dregs flour in making brownies combined with durian seed flour in this study. The resulting brownies have increased in quality, especially with the content of carbohydrates, fats, and proteins in these products.

Therefore, processing coconut dregs flour as a food ingredient can be done by substituting it with wheat flour in bread, cakes, cookies, and several other food preparations. The use of coconut dregs flour can reduce or reduce the use of coconut dregs to save wheat flour.

\section{Conclusions}

The levels of iron $(\mathrm{Fe})$ and zinc $(\mathrm{Zn})$ in coconut pulp flour were $44,075 \mathrm{mg} / \mathrm{kg}$ for iron $(\mathrm{Fe})$ and $24.2 \mathrm{mg} / \mathrm{kg}$ for zinc ( $\mathrm{Zn})$. For color criteria, the organoleptic characteristics of dregs flour are white and contain brown pollen. Standards for aroma, distinctively coconut scent. Texture criteria, in powder form. Taste criteria, normal. The highest percentage level of the hedonic scale for each standard was: $64 \%$ liked the color, $52 \%$ liked the aroma, $48 \%$ liked the texture somewhat, and $52 \%$ liked the taste. Based on these results, coconut pulp flour can be used as an alternative local food ingredient to meet iron and zinc needs in the body. Processing of coconut pulp flour as food can be used as a substitute or substitute for wheat flour in the manufacture of bread, cakes, cookies, and several other food preparations.

\section{Acknowledgment}

The researcher would like to thank the head of the Chemistry laboratory of FKIP Tadulako University, the head of the Palu health laboratory, Central Sulawesi province, and all those who have helped this research so that it can run well.

\section{References}

Alizah, N., Walanda, D. K., \& Hamzah, B. (2019). Analisis besi $(\mathrm{Fe})$ dan zink $(\mathrm{Zn})$ dalam buah merah (pandanus conoideus de vriese). Jurnal Akademika Kimia, 8(2), 88-91.

Aminah, S., Tamrin., \& Baco, A. R. (2018). Pengaruh subtitusi tepung ampas kelapa dan wortel (daucus carota 1) terhadap nilai organoleptik dan nilai gizi cookies. Jurnal Sains dan Teknologi Pangan, 3(5), 1652-1662.

Angelia, I. O. (2016). Analisis kadar lemak pada tepung ampas kelapa. Jurnal Technologi dan Entrepreneur, 4(1), 19-23.

Azis, R., \& Akolo, I. R. (2018). Karakteristik tepung ampas kelapa. Journal of Agritech Science, 2(2), 104-116.

Hamzah, H., \& Yusuf, N. R. (2019). Analisis kandungan zat besi $(\mathrm{Fe})$ pada daun kelor (moringa oleifera lam.) yang tumbuh dengan ketinggian berbeda di daerah kota Baubau. Indonesian Journal of Chemical Research, 6(2), 88-93.

Hasan, I. (2018). Pengaruh perbandingan tepung ampas kelapa dengan tepung terigu terhadap mutu brownies. Gorontalo Agriculture Technology Journal, 1(1), 59-67.

Herlambang, F. P., Lastriyanto, A., \& Ahmad, A. M. (2019). Karakteristik fisik dan uji organoleptik produk bakso tepung singkong sebagai substitusi tepung tapioka. Jurnal Keteknikan Pertanian Tropis dan Biosistem, 7(3), 253-258.

Herni, S., Tamrin, \& Asyik, N. (2018). Penilaian organoleptik serta proksimat biskuit tinggi serat berbasis tepung kaopi fermentasi dan ampas kelapa. Journal Sains dan Teknologi Pangan, 3(3), 1379-1392.

Kurniawati, S., \& Sugiarso, D. (2016). Perbandingan kadar Fe(II) dalam tablet penambah darah secara spektrofotometri Uv-vis yang dipreparasi menggunakan metode destruksi basah dan destruksi kering. Jurnal Sains dan Seni ITS, 5(1), C-1-C-5.

Lestari, T., Wahyuni, S. T., Mintarti, S. U., \& Churiyah, M. (2019). Economic empowerment of poor communities through diversification products of virgin coconut oil waste in Trenggalek district. International Journal of Scientific Research, 8(11), 19-22.

Mulyaningsih, T. R. (2013). Kandungan unsur Fe dan $\mathrm{Zn}$ dalam bahan pangan produk pertanian, peternakan dan perikanan dengan metode $\mathrm{k} 0$ AANI. Jurnal Sains dan Teknologi Nuklir Indonesia, 10(2), 71-80.

Mulyati, A. H., Widyiastuti, D., \& Muslimin, I. (2019). Characteristics of durian seed brownies which enriched with coconut flour. Journal of Science Innovare, 2(1), 6-9.

Ouma, O. G., Bonface, M. J., Baya, M. J., Omukhango, A. C., Kamau, G. G., Mae, H. M., \& Mwagandi, C. L. (2019). Growth performance, metabolic efficiency and nutrient utilization of BALB/C mice fed with diet made from leftovers from cocos nucifera pulp. American Journal of BioScience, 7(1), 1-6.

Putri, M. F. (2014). Kandungan gizi dan sifat fisik tepung ampas kelapa sebagai bahan pangan sumber serat. TEKNOGUBA: Jurnal Teknologi Busana dan Boga, 1(1), 32-43.

Putri, R. H., Chandradewi, A., Sofiyatin, R., \& Darawati, M. (2018). Sifat organoleptik dan kandungan zat gizi biskuit berbasis bahan pangan lokal. Jurnal Kesehatan Prima, 12(1), 30-40.

Rahmawati, A., Spartono., \& Cahyono, E. (2015). Kandungan kimia dan potensi beberapa jenis tepung ubi jalar pada pembuatan roti. Indonesian Journal of Chemical Science, 4(1), 610. 
Riskiyah, R. (2017). Peranan zinc pada penanganan kasus penyakit diare yang dialami bayi maupun balita. Journal of Islamic Medicine, 1(1), 22-29.

Saepulah, A., Julita, U., Yusuf, T., \& Cahyanto, T. (2017). Inovasi produk olahan pangan melalui pemanfaatan limbah organik ampas kelapa untuk meningkatkan ekonomi masyarakat kabupaten Bandung Jawa Barat. Jurnal Kajian Islam, Sains Dan Teknologi, 10(2), 91-106.

Handayani, N. A., Santosa, H.,Purbasari, A., Kusumayanti, H., \& Ariyanti, D. (2016). Fortifikasi seng ( $\mathrm{Zn})$ pada beras analog berbahan dasar tepung dan pati ubi ungu. Reaktor, 16(4), 183-188.

Silvia, D., \& Widodo, S. (2018). Mutu tepung ampas kelapa berdasarkan waktu pengolahan.
Prosiding Seminar Nasional Sinergitas Multidisiplin Ilmu Pengetahuan dan Teknologi Vol 1 (pp. 317-321). Makasar: Universitas Negeri Makasar.

Victor, E. E., \& Elijah, A. I. (2016). Optimization of coconut (Cocos nucifera) milk extraction using response surface methodology. International Journal of Nutrition and Food Sciences, 5(6), 384-494.

Widiastuti, D., Mulyati, A. H., \& Septiani, M. (2015). Karakteristik tepung limbah ampas kelapa pasar tradisoonal dan industri virgin coconut oil (VCO). Ekologia: Jurnal Ilmiah Ilmu Dasar dan Lingkungan Hidup, 15(1), 2934. 